\section{Mer selvmord blant ungdom på landet}

For amerikansk ungdom er selvmordsratene høyere på landet enn i byer og tettbebygde strøk. Forskjellen ser ut til å øke.

I en landsdekkende studie i USA ble det i perioden 1996-2010 registrert rundt 66600 selvmord hos ungdom i alderen 10-24 år (1). Selvmordsraten var dobbelt så høy i rurale strøk som i urbane strøk for både gutter (hhv. 19,9 og 10,3 selvmord per 100 000) og jenter (hhv. 4,4 og 2,4 per 100000 ). Forskjellen økte over tid. Og det ble vanligere med henging og andre kvelningsmetoder, mens bruk av våpen gikk ned.

- Denne studien viser at det er en sammenheng mellom bosted og selvmord hos ungdom i USA, men den kan ikke si sikkert at det å leve i rurale områder gir økt risiko for selvmord, påpeker Lars Lien, som er leder for Nasjonal kompetansetjeneste for samtidig rusmisbruk og psykisk lidelse, Sykehuset Innlandet, og professor ved Høgskolen i Hedmark. - Det kan snarere være andre risikofaktorer som samvarierer med grad av urbanisering, slik som tilgjengelighet til behandling og oppfølging av psykisk sykdom, sier han.

- Studien kan ha relevans også for Norge på grunn av økende fraflytting fra landsbygda og økende urbanisering. Det gir færre jobber og dårligere sosiale nettverk for dem som blir igjen i bygda, sier Lien.

\section{Tor Atle Rosness}

Tidsskriftet

\section{Litteratur}

1. Fontanella CA, Hiance-Steelesmith DL, Phillips GS et al. Widening rural-urban disparities in youth suicides, United States, 1996-2010. JAMA Pediatr 2015. E-publisert 9.3.

\title{
Langvarig effekt av hepatitt E-vaksine
}

\author{
Infeksjon med hepatitt E-virus er en vanlig årsak til akutt hepatitt. \\ Sykdommen er potensielt livstruende for utsatte grupper. Nå er lang- \\ tidseffekten av en vaksine mot viruset undersøkt.
}

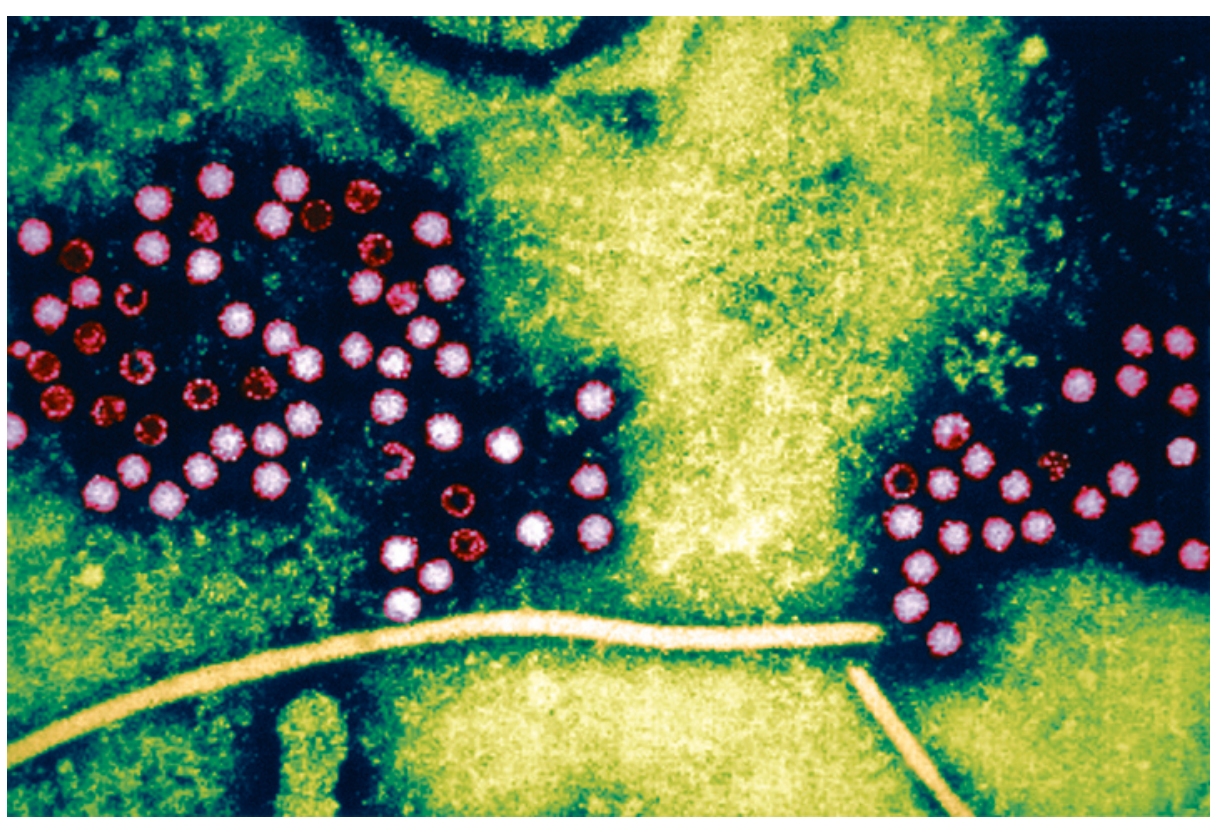

Illustrasjonsfoto: Science Photo Library

I en oppfølgingsstudie fra Kina er den beskyttende effekten av en vaksine mot hepatitt E-virus undersøkt (1). I 2007 ble 112604 friske voksne randomisert til enten å få tre doser med hepatitt E-vaksine eller tre doser med hepatitt B-vaksine i en fase 3-studie av korttidseffekt av vaksinene.

Deltakerne fra den opprinnelige studien ble fulgt i minimum fire år, med måling av antistoff-IgG mot hepatitt E-virus samt registrering av tilfeller av hepatitt. Diagnosen akutt hepatitt ble stilt hos pasienter med kliniske symptomer på sykdommen av varighet tre dager eller mer og samtidige ALATverdier på minst 2,5 ganger øvre normalverdi. Blodprøver fra disse pasientene ble deretter testet for å avgjøre hvilket hepatittvirus infeksjonen skyldtes.

I løpet av studieperioden ble det påvist sju tilfeller av hepatitt E-infeksjon i gruppen som fikk vaksine mot hepatitt E-virus 10,3 tilfeller per 10000 personår), og 53 tilfeller $\mathrm{i}$ gruppen som fikk vaksine mot hepatitt Bvirus (2,1 tilfeller per 10000 personår). Dette tilsvarte en vaksineeffektivitet på $86,8 \%$ (95\% KI 71-94\%).

Av deltakerne som var seronegative før vaksinering og fikk vaksine mot hepatitt E-virus, hadde $87 \%$ påvisbare antistoffer mot viruset etter 4,5 år. Av dem som fikk vaksine mot hepatitt B-virus, utviklet kun $9 \%$ antistoffer mot hepatitt $\mathrm{E}$.

Forskerne konkluderer med at immunisering med vaksine mot hepatitt E-virus ga vedvarende tilstedeværelse av antistoffer $\mathrm{i}$ blodet og beskyttelse mot hepatitt E-infeksjon i opptil 4,5 år.

\section{Matilde Risopatron Berg}

Sykehuset Innlandet, Elverum

\section{Litteratur}

1. Zhang J, Zhang XF. Huang SJ et al. Long-term efficacy of a hepatitis E vaccine. N Engl J Med 2015; 372: 914-22. 